\title{
Social Capital and IT Capital as a Factors Creating the Society of Knowledge
}

\author{
Hubert Kotarski \\ Institute of Sociology, Rzeszow University \\ Jaroslaw Kinal \\ Institute of Sociology, Rzeszow University \\ jaroslawkinal@gmail.com
}

Doi:10.5901/mjss.2014.v5n13p380

\section{Introduction}

All social capital theories refer to social factors, resources and relationships between those factors. What differentiates them in the detailed layer is the question, what aspects they high-light, what theory they use, which general paradigms they are based on. The theories differ with regard to the fact, if they highlight individual or collective/corporate actors (family, class, organization, group of neighbors, nation) as social capital "owners." Resources are another important aspect of social capital; they can considerably differ from each other in financial, cultural, psychological, social, or political terms. The third component involves relationships between the actors. It is probably central element of the concept, since it helps to single out social capital definitions. From the above it follows, that social capital can be restricted to less or more closed networks (class, family, persons), or it can have an impact beyond the observable networks of individual and collective actors (town district, town, province).

\section{Definition of Information Society}

The information society is such a society, where information has become the most important element of life in possession of information which determines the possession of power (Van Dijk, 2010: 367). Jerzy Stanislaw Nowak (2006: 25-49) in his article "Information Society - origins and definitions", presents a number of definitions, which indicate that the information society is characterized by the ability to process information through the use of modern technology. The term information society appeared for the first time in $\mathbf{5 0}$ years of the twentieth century, in the context of the analysis of the U.S. economy sector, made by Fritz Machlup. In his work, he predicted that the sector of information services will be the fastest growing sector, which will mean that the United States will become a society dependent on knowledge and information. The next step in the development of the information society have been 70 years of the twentieth century, when modern technology has enabled the computerization of many works. According to Tomasz Goban-Class and Peter Sienkiewicz most important for this concept is to link the computers with the means of communication, which in a way beneficial effect on the efficiency of intellectual property and controlled by its production and distribution of goods (GobanKlas, Sienkiewicz, 1999: 53). Therefore, they define the information society as one that: not only has developed measures of information processing and communication, but the processing of information is the basis for the creation of national income and provides a source of income for most of society (Goban-Klas, Sienkiewicz, 1999: 53). Features information society perfectly presented Daniel Bell describing the post-industrial society, which is characterized by:

1) Domination of the service sector in the economy, as well as the fourth sector (ie, insurance and finance) and fifth (ie, science, education, health).

2) increase the importance of professionals and researchers in the occupational structure.

3) The meaning of theoretical knowledge as a source of innovation.

4) By setting to control the development of technology.

5) the creation of new intellectual technologies that will form the basis for decision-making social and political (Goban-Klas, Sienkiewicz, 1999: 53).

These traits also indicate the information society plan Yoneji Masudy - the plan to create an information society as a national goal for 2000, in which he stressed the importance of raising the intellectual capacity of people, computerization of education and create a computer network (Goban-Klas, Sienkiewicz, 1999: 53).

In the context of education there has been a shift from individuals master in agrarian society, through an increase 
in the importance of education in industrial society, to a significant share of computers in education in the information society (Goban-Klas, Sienkiewicz 1999-1954).

\section{Knowledge Society}

The concept of the knowledge society is a broader scope as the name of the information society, because the knowledge gained in the long process of cognition, using research methods, resulting in it shall be revealed, and thus creates information. Writing about the knowledge society, the authors of the work they have in mind mainly scientific knowledge, in the form of innovation, which is the basis of social learning processes (Lis 2013: 15-20). The development of social knowledge is dependent on academic merit, their distribution by educational systems, the popularization of the use of modern information and communication technologies (Kulpińska, 2008: 27). Can therefore be assumed that the knowledge society combines the information society and knowledge economy. It can also be defined by three dimensions: 1) the development of science, education and technology; 2) complex formation and distribution of knowledge for economic purposes; and 3) the institutions of learning. A man living in a knowledge society must be mobile and actively participate in the creation of the reality around him, he should also move freely in the sheer volume of information coming to him. Member of the knowledge society should be able to distinguish useful information from the information "junk", because as far as the information reaches the most people in the world, this knowledge is still the privilege of the few (Lis 2013: 20-24). Such a society can be divided into the following features:

1) Setting members of the public to learn throughout life.

2) Increase the number of knowledge workers, or creative practitioners.

3) Creation of scientific knowledge for practice.

4) Rely on the economy and policy knowledge.

5) The existence of intelligent organization and intelligent goods (Lis 2013: 20-24).

\section{Digital Competences}

As digital competences can be determined skillful and critical use of information society technology for work, leisure and communication. They are based on basic skills in ICT: the use of computers to retrieve, assess, store, produce, present and exchange information, and to communicate and participate in collaborative networks via the Internet (Piecuch 2012).

In the literature can be found also the division into:

1. Information literacy

2. Informatics literacy

3. Digital literacy

Information Literacy (information literacy - IL) can be defined as a complex set of capabilities necessary to recognize when information is needed and required that the entity could recognize the need for information, it knew how to locate, evaluate, and use effectively. In the context of new media competence can be understood as information selection, gathering information and creating information. It is connected with the change of the model of participation in the media and the transition from a passive recipient of content to prosumer. The prosumer concept has been described by Alvin Toffler in his book "The Third Wave" published in the 70s XX century. Syntactically, it is a combination of the English word professional or producer with the consumer. As indicated A. Toffler (2006), prosumer is more than a consumer. This is a person who has a vast knowledge of products and services related to the favorite brand and communicate this knowledge to others. It's someone who wants to have an active part in the development of products and services and has a higher brand awareness when making purchasing decisions. In other words, the prosumer is an active consumer who is not just a passive recipient of advertising materials. Way to stimulate the customer to action is to make the prosumer, ie co-participant of the product and its promotion. Prosumer is a partner of the manufacturer, and communication with him reminds continuous dialogue.

Informatical literacy can be defined as the ability to use technology in everyday life. On the competences consists of a good knowledge and ability to use the so-called. information society technologies (IST) in various situations: at work, at leisure, as a communication tool. Based on the basic skills: using computers and other media to capture, assess, collect, produce, present and exchange information, and to communicate and participate in networking. Podstawa jest: rozumienie i znajomość głównych aplikacji komputerowych (MS Word, MS Excel, baz danych, archiwizowanie informacji), świadomość możliwości, jakie daje korzystanie z Internetu i komunikowanie się przy użyciu mediów elektronicznych (email, videokonferencje). Istotne jest również sprawne rozpoznawanie różnić pomiędzy światem rzeczywistym i wirtualnym,oraz rozumienie potencjału IST jako wsparcia kreatywności i innowacyjności w rozwoju osobistym (Sysło 


\section{Social Capital - Terms and Concepts}

In various academic publications, there are many definitions of social capital. One can, however, try to look for some common elements of different social capital theories. Such generalization was conducted by John Field in his book: Social Capital. Key Ideas (Field, 2003). All social capital theories refer to social factors, resources and relationships between those factors. What differentiates them in the detailed layer is the question, what aspects they highlight, what theory they use, which general paradigms they are based on. The theories differ with regard to the fact, if they highlight individual or collective/corporate actors (family, class, organization, group of neighbors, nation) as social capital "owners." Resources are another important aspect of social capital; they can considerably differ from each other in financial, cultural, psychological, social, or political terms. The third component involves relationships between the actors. It is probably central element of the concept, since it helps to single out social capital definitions. From the above it follows, that social capital can be restricted to less or more closed networks (class, family, persons), or it can have an impact beyond the observable networks of individual and collective actors (town district, town, province).

For the first time, the term social capital was used "not by some cloistered theoretician, but by a practical reformer of the Progressive Era - Lyda J. Hanifan, state supervisor of rural schools in West Virginia. Writing in 1916 to urge the importance of community involvement for successful schools, Hanifan invoked the idea of "social capital» to explain why" (Putnam, 2008, pp. 33-34). It is commonly believed, however, that the broad interest in social capital was initiated by theoretical systematization of that term by four authors: Pierre Bourdieu, James Coleman, Robert Putnam, and Francis Fukuyama.

The first systematic analysis of the term social capital was developed by Pierre Bourdieu. Let us point out, that that French sociologist defines social capital as "sum of the resources, actual or virtual, that accrue to an entity or a group by virtue of possessing a durable network of more or less institutionalized relationships of mutual acquaintance and recognition" (Bourdieu \& Wacquant, 2001, p. 105). Due to being part of a network, the entity gains access to the capital owned by all network members who are linked together by the relations of mutual trust. The social capital asset owned by an entity depends on the size of network that the entity is able to mobilize effectively, on the scope of the capital (symbolical, economic, cultural) owned by every person, that the given entity is linked with, as well as on the amount and quality of those resources (Rymsza, 2007, p. 24). According to Bourdieu, social capital is one of three forms of capital, which can be used in order to gain and maintain the privileged position within the field (meaning a complex, defined as a network of objective, historical relations between positions anchored in some particular forms of power or capital). The field - just that specific position is the stake in the game. The author defines, however, forms of capital in a dynamic manner, regarding "game strategies" as activities aimed, first of all, at conversion of capitals (Theiss, 2007, p. 17). Social capital in terms of Bourdieu gives the individuals access to other forms of capital - economic or cultural ones. It is also a rational investment of economic or cultural resources.

James Coleman is another outstanding theoretician that researched the concept of social capital. He used for the first time in a scientific study the term "social capital". Coleman is the author of definition that is regarded as the classical definition for the entire systematic approach to social capital defined as an economic perspective (theory of rational action) (Trutkowski \& Mandes, 2005). It was presented in his most famous work, Foundations of Social Theory (Coleman, 1990), in which the system of sociology is based on rational choice theory. In that work, the author rejects the approach of neoclassical economics, according to which the individual strives exclusively to maximization of utility, as well as the sociological tradition that the essential causative power in respect of human actions ascribes to socially shaped standards (Theiss, 2007, p. 14). Coleman regarded social capital as "ability of humans to cooperation within groups and organizations of common interests" (Fukuyama, 1997). According to the American sociologist, social capital can be regarded as "a variety of different entities having two characteristics in common: They all consist of some aspect of social structures, and they facilitate certain actions of individuals who are within that structure. Like other forms of capital, social capital is productive, making possible the achievement of certain ends that would not be attainable in its absence." (Coleman, 1988, p. 98). According to J. Coleman, social capital is a feature of social relationships structure supporting the concrete actions of actors conducted within that structure (Theiss, 2007, p. 14).

The third great theoretician of social capital concept - Robert Putnam - can be regarded as continuator of James Coleman's thought. Putnam defined social capital as "features of social organization such as networks, norms, and social trust that facilitate coordination and cooperation for mutual benefit" (Putnam, 1997, p. 31). However, the term social capital is used by him in a different context than by Coleman, since he attempts to find out what factors cause that twenty years after the administrative reform establishing in Italy regional governments, a significant differentiation concerning the 
level of their efficiency and effectiveness can be observed (Theiss, 2007, p. 16). According to Putnam, the decisive role in the success of North Italian regions and failure of South Italian ones plays the social capital consisting of "values of associate life within the given society such as networks, standards and trust - those values make it possible for the members of the given society to increase the effectiveness of common actions and achieve objectives shared by them in a more efficient way" (Putnam, 1995, p. 56). One of the most characteristic features of social capital including trust, standards, networks of associations, is the fact, that unlike other forms of capital, it is usually public and not private good and, like other public goods, it is underinvested and not sufficiently appreciated by entities (Rymsza, 2007, p. 31). But trust is regarded by Robert Putnam as the most important component of social capital.

The fourth prominent theoretician of social capital issues is Francis Fukuyama. He occupies himself with social capital problems by analyzing the impact of culture on economy. In his publication, Trust, The Social Virtues and the Creation of Prosperity, he argues that prosperity of a country and its ability to economic competitiveness depend on the trust level of its inhabitants (Fukuyama, 1997). It is understood as a mechanism based on the assumption, that other members of a given community feature honest and cooperative behavior based on commonly followed standards that can be derived from religious sources, legal regulations or customs.

On the other hand, social capital is defined by F. Fukuyama as ability (potential) resulting from the prevalence of trust within the society or a part of it. It can be a feature of family, nation and intermediate groups. Its most important function is the creation of new relationships between people or social groups and acting in accordance with standards defined by them. Trust is based on the assumption that other members of a given community feature honest and cooperative behavior based on commonly followed standards that can be derived from religious sources, legal regulations or customs (Theiss, 2007, p. 18). According to Fukuyama: social capital is an instantiated informal norm that promotes cooperation between two individuals, or a greater number of them (Fukuyama, 2001, p. 13)

\section{Social Capital as a Factors Creating the Society of Knowledge}

Formal membership in one of the officially existing associations is one of social capital aspects. However, it often is regarded as a useful barometer of social involvement. Advantages of associations were already described by Alexis de Tocqueville, who, giving the example of American society, stated as follows: Americans of all ages, all conditions, all minds constantly unite. Not only do they have commercial and industrial associations in which all take part, but they also have a thousand other kinds: religious, moral, grave, futile, very general and very particular, immense and very small [...] Thus the most democratic country on earth is found to be, above all, the one where men in our day have most perfected the art of pursuing the object of their common desires in common and have applied this new science to the most objects (Tocqueville, 1996, p. 116). Also Robert Putnam states that civil associations contribute to effectiveness and stability of a democratic government due both to their "internal" impact on individual members and "external" effect on the wider community. By their internal influence, associations instill their members into habits of cooperation, solidarity and thinking about social issues. By their external impact, the dense network of secondary connections strengthens "what political scientists have called interest articulation and interest aggregation" (Putnam, 1995, p. 137). For most theoreticians not only one of the features, i.e. association of citizens, but the generally recognized social capital is the essence of civil society, and for sure a developmentally effective society (Czapiński \& Panek, 2007, p. 257).

Trust is an essential component of social capital and one of its most precious types (Sztompka, 2007, p. 244). For many theoreticians, it is the key category and value, and its presence proves a high social capital level (Szawiel, 2006). As highlighted by Andrzej Sadowski, the high level of social trust between people occurring within families and voluntary established social institutions and organizations results in inhabitants' readiness to take up cooperation, team work, in order to achieve specified objectives. Robert Putnam, one of the promoters of the term social capital, turned his attention to the relationship between social capital and trust. As we remember, he defined the term social capital as: "features of social organizations, such as trust, norms and networks that can improve the efficiency of society by facilitating coordinated actions" (Putnam, 1995, p. 258). Putnam clearly emphasized that trust is "an essential component of social capital" (Putnam, 1995, p. 264). Trust is, first of all, the result of positive experience related to civil cooperation and possibility to propagate that kind of knowledge among other people; that is why possibilities available to communities concerning dissemination of such information are important for the level of social capital (Lewenstein, 2006, p. 165).

Summing up many years of empirical research and theoretical analyses conducted by various researchers, David Halpern concluded that "trust and reliability are the significant aspect of normatively understood social capital" (Sztompka, 2007, pp. 244-245). Many empirical studies regard the trust level as one of the simplest and single indicators of social capital. According to Piotr Sztompka, a strong justification of such action was delivered by Putnam, who conducted a comparative research on the social capital level in a dozen of US states. For the purpose of that research, he developed 
a complex social capital index, including such components as membership in voluntary associations, attendance at their meetings, participation in public meetings, mass meetings, etc., taking up voluntary activities for the benefit of community, organization of parties for friends, attendance at such parties, participation in elections and generalized trust. It turned out that the strongest correlation occurs between the acceptance by respondents of the notion: "You can trust most people" an indicator of generalized trust, and other index components. In consequence, trust must be considered as the nucleus of social capital (Sztompka, 2007, p. 245).

According to Robert Putnam's argumentation, being a citizen in a community means, first of all, an active participation in public matters (Putnam, 1995, p. 133). It is difficult not to agree with this statement. Another academic, Michael Walzer, wrote about the need of civic in-volvement as follows: "public interest issues and dedication to public purposes are key signs of civic virtues" (Walzer, 1980). Civic engagement and willingness to cooperation for the ben-efit of society are essential features of social capital. The higher the level of willingness to tak-ing up common actions, the higher are chances for development and a better functioning of society. According to statement of the previously mentioned Robert Putnam, "networks of civic engagement foster sturdy norms of generalized reciprocity, [...] facilitate communication and improve the flow of information. And the better the flow of information between part-ners, both direct and indirect ones, the greater is their mutual trust and easier the cooperation (Putnam, 1995, p. 270).

\section{References}

Bourdieu, P. i Wacquant, L. J. (2001). Zaproszenie do socjologii refleksyjnej. Warszawa: "Oficyna Naukowa".

Coleman, J. S. (1988). Social Capital in the Creation of Human Capital. American Journal of Sociology(ol. 94, Supplement: Organizations and Institutions: Sociological and Economic Approaches to the Analysis of Social Structure).

Czapiński, J. i Panek, T. (2007). Diagnoza społeczna 2007 : warunki i jakość życia Polaków : raport. Warszawa: Vizja Press\&\&T.

Field, J. (2003). Social capital. Key ideas. London, New York: Routledge.

Fukuyama, F. (1997). Zaufanie : kapitał społeczny a droga do dobrobytu. Warszawa ; Wrocław: Wydawnictwo Naukowe PWN.

Fukuyama, F. (2001). Social capital, civil society and development. Third World Quarterly, 22(1).

Kulpińska N. (2008) Społeczeństwo wiedzy - praca nad wiedza. [in:] Siwik A., Haber L.H. (ed.) Od robotnika do internauty. W kierunku społeczeństwa informacyjnego. 40-lecie socjologii w Akademii Górniczo-Hutniczej. AGH Uczelniane Wydawnictwo NaukowoDydaktyczne, Kraków.

Lewenstein, B. (2006). Społeczeństwo rodzin czy obywateli - kapitał społeczny Polaków okresu transformacji. Societas Communitas(1).

Lis S. (2013) Wybrane cechy społeczeństwa wiedzy. [in:] Lis S., Ziemba M. (ed.) Społeczeństwo wiedzy. Uwarunkowania społeczne i kulturowe. Wydawnictwo Państwowej Wyższej Szkoły Zawodowej im. prof. Stanisława Tarnowskiego, Tarnobrzeg.

Nowak J. S. (2006) Społeczeństwo Informacyjne - Geneza i definicje. [in:] Sienkiewicz P.,

Nowak J. S. (ed.) Społeczeństwo informacyjne. Krok naprzód, dwa kroki wstecz. Polskie Towarzystwo Informatyczne. Oddział Górnoślaski, Katowice s. 25-49.

Piecuch A. (2007) Kompetencje informacyjne. [in:] Pavelka J. (ed.) InEduTech: Kl'́čové kompetencie a technické vzdelávanie: III Medzinárodná vedecko-odborná videokonferencia, Prešovská Univerzita, Prešov, s. 120-127

Putnam, R. D. (1995). Demokracja w działaniu : tradycje obywatelskie we współczesnych Włoszech. Kraków: "Znak".

Putnam, R. D. (2008). Samotna gra w kręgle. Upadek i odrodzenie wspólnot lokalnych w Stanach Zjednoczonych. Warszawa: Wydawnictwa Akademickie i Profesjonalne.

Rymsza, A. (2007). Klasyczne koncepcje kapitału społecznego. W T. Kaźmierczak i M. Rymsza (Redaktorzy), Kapitał społeczny. Ekonomia społeczna. Warszawa: Fundacja Instytut Spraw Publicznych.

Sysło M. (2012) Technologia informacyjna w edukacji. http://www.snti.pl/snti/files/ti_w_edukacji.pdf

Szawiel, T. (2006). Społeczeństwo obywatelskie i kapitał społeczny w Polsce na przełomie wieków (1995-2001). W A. Miszalska i A. Piotrowski (Redaktorzy), Obszary ładu i anomii. Konsekwencje i kierunki polskich przemian. Łódź: Wydawnictwo Uniwersytetu Łódzkiego.

Sztompka, P. (2007). Zaufanie: fundament społeczeństwa. Kraków: Społeczny Instytut Wydawniczy Znak.

Theiss, M. (2007). Krewni, znajomi, obywatele : kapitał społeczny a lokalna polityka społeczna. Toruń: Wydawnictwo Adam Marszałek.

Trutkowski, C. i Mandes, S. (2005). Kapitał społeczny w małych miastach. Warszawa: Wydawnictwo Naukowe "Scholar".

Van Dijk J. (2010) Społeczne aspekty nowych mediów. Analiza społeczeństw sieci. PWN, Warszawa.

Van Dijk J. (2013) Ewolucja wykluczenia cyfrowego. Od dostępu po kompetencje i użytkowanie. [W:] Pokrzywa M., Wilk S. (red.) Wykluczenie społeczne. Diagnoza, wymiary, kierunki działań. Wydawnictwo Uniwersytet Rzeszowski, Rzeszów, s.207-232.

Walzer, M. (1980). Civility and Civic Virue in Contemporary America. W M. Walzer (Red.), Radical Principles: Reflections of an Unreconstructed Democrat. New York: Basic Books. 